\title{
Concentrations of erythromycin and azithromycin in mature Chinook salmon Oncorhynchus tshawytscha after intraperitoneal injection, and in their progeny
}

\author{
William T. Fairgrieve ${ }^{1, *}$, Cyndy L. Masada ${ }^{2}$, Mark E. Peterson ${ }^{2}$, W. Carlin McAuley ${ }^{2}$, \\ Gail C. McDowell ${ }^{1}$, Mark S. Strom ${ }^{2}$
}

${ }^{1}$ Pacific States Marine Fisheries Commission, 205 South East Spokane Street Suite 100, Portland, Oregon 97202, USA

${ }^{2}$ National Marine Fisheries Service, Northwest Fisheries Science Center, 2725 Montlake Blvd. East, Seattle, Washington 98112, USA

\begin{abstract}
A single dose $\left(40 \mathrm{mg} \mathrm{kg}{ }^{-1}\right)$ of erythromycin or azithromycin dihydrate was injected intraperitoneally into maturing female fall Chinook salmon 12 to $32 \mathrm{~d}$ before spawning to observe the distribution, retention and clearance of the drugs in plasma, kidney, coelomic fluid and egg vitellin, and their persistence in alevins derived from these fish. Salmon administered prophylactic dosages of erythromycin as subadults were also included to investigate potential interactive effects of oral and injected treatments on reproductive performance and antibiotic clearance. Erythromycin was rapidly cleared from plasma and coelomic fluid, but was detected in the kidney (3.52 to $12.40 \mathrm{\mu g} \mathrm{g}^{-1}$ ) and egg vitellin (5.32 to $\left.8.87 \mathrm{\mu g} \mathrm{ml}^{-1}\right)$ of all fish at spawning. High, stable concentrations of azithromycin were detected in plasma (14.66 to $20.33 \mu \mathrm{g} \mathrm{ml}^{-1}$ ), kidney (43.16 to $\left.59.96 \mathrm{\mu g} \mathrm{g}^{-1}\right)$, coelomic fluid (2.52 to $5.50 \mu \mathrm{g} \mathrm{ml}^{-1}$ ) and egg vitellin (12.65 to $23.51 \mathrm{\mu g} \mathrm{ml}^{-1}$ ). Oral administration of erythromycin to subadult salmon did not significantly affect tissue concentrations of either erythromycin or azithromycin administered by prespawning injection. Reductions in the percentage of eggs that yielded live embryos at the eyed stage of development occurred among eggs derived from females that had received orally administered erythromycin as subadults. Erythromycin was not detected in unfed fry derived from adults injected with the drug prespawning, but azithromycin was present for more than 2 mo after the onset of exogenous feeding.
\end{abstract}

KEY WORDS: Renibacterium salmoninarum · Macrolide antibiotics · Adult Chinook salmon

\section{INTRODUCTION}

Bacterial kidney disease (BKD), caused by the fastidious, slow-growing gram-positive bacterium Renibacterium salmoninarum, is a severe systemic infectious disease of wild and hatchery-reared salmonids worldwide (Toranzo et al. 1990, Sakai \& Kobayashi 1992, Fryer \& Lannan 1993). Long implicated in catastrophic losses among hatchery populations of juvenile Pacific salmonids (Earp et al. 1953), the disease has emerged as the major factor limiting successful captive rearing of endangered salmon species in western North America (Flagg et al. 1995).
The macrolide antibiotic erythromycin has long been the chemotherapeutant of choice to prevent and control Renibacterium salmoninarum infections in salmonids (Elliott et al. 1989). In captive broodstock programs rearing endangered Pacific salmon, subadult fish are treated prophylactically using erythromycin as a feed additive, administered at daily dosages of $100 \mathrm{mg} \mathrm{kg}^{-1}$ for 21 to $28 \mathrm{~d}$ of continuous therapy (Wolf \& Dunbar 1959, Peters \& Moffitt 1996). Then, because eggs may acquire infections during oogenesis (Lee \& Gordon 1987) and following ovulation when they are surrounded by contaminated coelomic fluid (Lee \& Evelyn 1989), maturing adult salmon are given a single 
injection of erythromycin $\left(40 \mathrm{mg} \mathrm{kg}^{-1}\right) 4 \mathrm{wk}$ before spawning occurs. Residues can persist in the ova of maturing salmon for up to $60 \mathrm{~d}$ post-injection (Bullock \& Leek 1986) and may reduce (Lee \& Evelyn 1994), but not eliminate (Brown et al. 1990), vertical transmission of viable bacteria to the progeny of infected adults. There are no proven vaccines available to prevent BKD in Pacific salmon, and treatment is complicated by the ability of the organism to survive phagocytosis by macrophages (Bandin et al. 1993, Gutenberger et al. 1997). Thus, there is a clear need for alternative chemotherapeutants for use in captively-reared endangered stocks.

Azithromycin is a semisynthetic macrolide drug derived from erythromycin with greatly improved extravascular penetration, tissue distribution, and a longer elimination half-life in serum and tissues in mammalian models (Girard et al. 1987). Azithromycin achieves high concentrations in phagocytic cells and fibroblasts of mammals and, compared with erythromycin, has demonstrated superior clinical efficacy against a variety of intracellular pathogens (Peters et al. 1992).

Azithromycin has strong in vitro bactericidal activity against Renibacterium salmoninarum (Fryer 1987) and demonstrated in vivo efficacy in experimentally infected juvenile salmonids (Strom et al. 2000). It was exceptionally well-absorbed from the diet by juvenile fall Chinook salmon Oncorhynchus tshawytscha, and exhibited a half-life more than 3-fold longer than that of erythromycin (Fairgrieve et al. 2005). The improved pharmacokinetic profile, broad spectrum of activity, and superior performance in controlling facultative intracellular pathogens make azithromycin an important antimicrobial drug to test on maturing salmon.

This paper describes the distribution, retention and clearance of injectable erythromycin and azithromycin from the plasma, kidney, coelomic fluid and egg vitellin of sexually mature female fall Chinook salmon, and the persistence of these antibiotics in alevins derived from these fish. Maturing salmon that had been administered prophylactic dosages of erythromycin in the hatchery as subadults were specifically included to investigate potential interactive effects of oral and injected treatments on reproductive performance and antibiotic clearance.

\section{MATERIALS AND METHODS}

Experimental conditions. Unfed fall Chinook salmon fry (initial weight $0.42 \mathrm{~g}$ ) obtained in January 1999 were reared at the University of Washington Big Beef Creek Research Hatchery (Seabeck, Washington, USA) in 1.83 m diameter (1250 l) circular polyethylene tanks supplied with $10 \mathrm{l} \mathrm{min}^{-1}$ of well water $\left(10^{\circ} \mathrm{C}\right)$. The fry were acclimated to laboratory conditions for $14 \mathrm{~d}$, and fed to apparent satiation 4 to 6 times daily with a semi-moist starter diet (Bio-Oregon). Thereafter, a growth model based on the delta-l method (Butterbaugh \& Willoughby 1967) was used to calculate the daily ration of a dry commercial salmon feed (Nutri-fry salmon diet, Moore-Clark) required to produce smolts of ca. $16 \mathrm{~g}$ by 15 June 1999.

At smoltification, 280 fish were tagged internally with passive integrated transponders (PIT-tags) and distributed randomly to four $4.0 \mathrm{~m}$ diameter (12 $000 \mathrm{l}$ ) tanks. Flow $\left(135 \mathrm{l} \mathrm{min}^{-1}\right)$ and temperature $\left(10^{\circ} \mathrm{C}\right)$ were held constant in each tank. Duplicate groups of fish, (designated E-2) were fed a dry commercial salmon diet (Chinook AB salmon diet, Moore Clark) medicated with erythromycin phosphate (Abbot Laboratories; $74.5 \%$ anhydrous potency) twice a year for $2 \mathrm{yr}$, beginning in early December 1999 and ending in late June 2001. Dietary drug concentrations and feeding rates were adjusted during each feeding period to deliver a daily dose of $100 \mathrm{mg} \mathrm{kg}^{-1}$ for $28 \mathrm{~d}$. The unmedicated diet was fed to duplicate tanks of control fish throughout the study and to the E-2 groups between periods of antibiotic treatment.

Fish that matured in September or October 2001 were removed from the population and used in a concurrent study on the effects of erythromycin on ovarian development and egg quality (Fairgrieve et al. 2004). Immature fish were combined into a single $4 \mathrm{~m}$ diameter tank and fed the unmedicated diet until late July 2002, when feeding was terminated. Fish exhibiting signs of impending maturity in late August were tagged (according to their respective dietary treatment regimen) with colored plastic wire-ties inserted through the base of the dorsal fin. On 6 September 2002 all female fish received a single intraperitoneal dose $\left(0.4 \mathrm{ml} \mathrm{kg}^{-1}=40 \mathrm{mg} \mathrm{kg}^{-1}\right)$ of either injectable azithromycin dihydrate (Zithromax ${ }^{\circledR}$ [azithromycin for injection]; Pfizer) reconstituted with demineralized water $\left(100 \mathrm{mg} \mathrm{ml}^{-1}, \mathrm{w} / \mathrm{v}\right)$, erythromycin (Gallimycin ${ }^{\circledR}$ 100; Bimeda), or demineralized water. The injected treatments were assigned to female fish within each dietary treatment group as they were captured randomly from the tank. Males were not treated with antibiotics. Female fish in each injected treatment group were identified with a second color-coded wiretie inserted at the time of injection. All fish were returned to the tank immediately after injection. No post-injection mortalities occurred in any treatment group.

On 18, 23, 30 September and 8 October $(12,17,24$ and $32 \mathrm{~d}$ post-injection) the fish were sorted and ripe females spawned. Female fish were anesthetized (tricaine methanesulfonate, $50 \mathrm{mg} \mathrm{l}^{-1}$; Argent Laborato- 
ries), sacrificed by cervical dislocation, and the eggs removed through an incision extending from the vent to the pectoral fins along the ventral midline. Unfertilized eggs and coelomic fluid were collected in individual labeled plastic bags and stored on ice for up to $4 \mathrm{~h}$ before fertilization. Milt, collected by stripping from anesthetized fish, was stored on ice in separate oxygen filled Whirlpak ${ }^{\circledR}$ (Nasco) bags for up to $1 \mathrm{~h}$ before use.

At spawning, samples of whole blood, kidney, coelomic fluid and unfertilized eggs were collected for measurement of antibiotic concentrations. Blood was sampled from the caudal vessel using Vacutainer ${ }^{\circledR}$ (Becton Dickinson) evacuated blood-sampling equipment $(47 \times 10.25 \mathrm{~mm}$ tube, $2 \mathrm{ml}$ draw volume) with heparin and plasma isolated by centrifugation at $425 \times$ $g$ for $10 \mathrm{~min}$. Coelomic fluid was collected in $10 \mathrm{ml}$ (full volume) polypropylene pipets. Plasma and coelomic fluid were transferred to polypropylene microcentrifuge tubes for storage. Samples of eggs and kidney were placed into separate Whirlpak ${ }^{\circledR}$ bags. All samples were stored frozen $\left(-20^{\circ} \mathrm{C}\right)$ for 21 to $41 \mathrm{~d}$, until analyzed.

Eggs and milt were combined in single male-female crosses according to dietary treatment group. Coelomic fluid was drained from the eggs and 5 to $10 \mathrm{ml}$ of milt added. After $10 \mathrm{~min}$, the fertilized eggs were rinsed with plain hatchery water and transferred to Heath trays (MariSource) for incubation $\left(10^{\circ} \mathrm{C}, 121\right.$ $\mathrm{min}^{-1}$ ). At the eyed stage of development (330 degreedays, $\left.{ }^{\circ} \mathrm{D}\right)$ the eggs were shocked, counted and the percentage of viable (live) embryos determined.

Patterns of drug clearance were determined using fry from selected groups in which antibiotic residues had been detected. Unfed fry were weighed and counted at swim-up $\left(920^{\circ} \mathrm{D}\right)$ and samples collected for antibiotic analysis. Confirmatory analysis was conducted with fish collected 7 d later. The progeny of 9 azithromycin-injected females (erythromycin was not detected in unfed fry) and 4 females injected with demineralized water were transferred to the Northwest Fisheries Science Center (Seattle, Washington, USA) fish pathology laboratory $14 \mathrm{~d}$ after swim-up. Approximately 250 fry from each group were placed into separate $0.28 \mathrm{~m}$-diameter $(13.0 \mathrm{l})$ circular fiberglass tanks. Flow $\left(1.41 \mathrm{~min}^{-1}\right)$ and temperature $\left(12^{\circ} \mathrm{C}\right)$ were constant during the depletion phase of the experiment. All fish were fed a semi-moist fry feed (BioOregon) to apparent satiation. Initially, the daily ration was administered in 4 feedings (at 08:00, 10:00, 12:00 and 14:00 h), which was reduced to twice daily after $42 \mathrm{~d}$. Feed was withheld for $24 \mathrm{~h}$ before each weekly sampling.

Fry were sampled weekly until antibiotic residues were no longer detected (85 d). From each tank, 10 randomly selected fry were sacrificed (tricaine methanesulfonate, $200 \mathrm{mg} \mathrm{l}^{-1}$ ), blotted dry with paper towels, and placed into preweighed Whirlpak ${ }^{\circledR}$ bags. Samples were stored on ice for $<24 \mathrm{~h}$ before analysis.

Sample processing and antibiotic assay. Frozen samples were thawed at room temperature for 1 to $3 \mathrm{~h}$ before analysis. Kidney samples and whole fish were placed into Whirlpak ${ }^{\circledR}$ bags, weighed, and phosphate buffer solution ( $\mathrm{pH} 7.2)$ added (1:1 w:v). The samples were homogenized with a rubber roller. Unfertilized eggs (ca. $10 \mathrm{~g}$ ) were homogenized without added buffer and the vitellin was transferred to polypropylene microcentrifuge tubes for storage. Coelomic fluid and blood plasma were analyzed without additional processing.

The concentration of erythromycin and azithromycin in fish tissue was determined microbiologically as described by Evelyn et al. (1986a,b) using the bacterium Micrococcus luteus, which is sensitive to erythromycin concentrations as low as $0.00025 \mu \mathrm{g} \mathrm{ul}^{-1}$ sample. The plate base layer (45 $\mathrm{ml}$ of Difco Antibiotic Medium 11, Difco Laboratories) was poured into $150 \times$ $15 \mathrm{~mm}$ sterile Petri dishes and overlaid with $13.5 \mathrm{ml}$ Difco antibiotic medium 11 inoculated with $0.2 \mathrm{ml}$ of a M. luteus culture (optical density of 1.0 at $540 \mathrm{~nm}$ ). We distributed 5 sterile $7 \mathrm{~mm}$ paper disks (Becton Dickinson Microbiology System) evenly around the periphery of each inoculated plate, and placed a sixth disk in the center. Aliquots $(10 \mu \mathrm{l})$ of the sample preparations were pipetted onto the peripheral disks. An aliquot $(10 \mu \mathrm{l})$ of erythromycin or azithromycin reference standard $\left(2.0 \mu \mathrm{g} \mathrm{ml}^{-1}\right)$ was transferred by micropipette to the center disk of each plate. Plates were incubated at $30^{\circ} \mathrm{C}$ for $24 \mathrm{~h}$, after which the diameter of the zones of inhibition were measured to the nearest $0.5 \mathrm{~mm}$. Antibiotic concentration in each test disk was calculated from a standard curve (inhibition zone diameter versus $\log _{10}$ antibiotic concentration in $\mu \mathrm{g} \mathrm{ml}^{-1}$ ) and corrected for dilution to determine equivalent antibiotic concentrations in the tissues ( $\mu \mathrm{g} \mathrm{g}^{-1}$ wet wt). Tissues and egg vitellin from fish not injected with antibiotics were tested and did not inhibit growth of $M$. luteus. Detection limits for antibiotics were $0.5 \mathrm{\mu g} \mathrm{g}^{-1}$ (kidney, whole fish) and $0.25 \mu \mathrm{g} \mathrm{ml}^{-1}$ (egg vitellin, plasma, coelomic fluid).

Statistical methods. The concentrations of azithromycin or erythromycin in blood plasma, kidney, coelomic fluid and vitellin from unfertilized eggs and unfed fry were tabulated for each treatment group. For each tissue, the influence of orally-administered erythromycin on the accumulation of injected antibiotic was evaluated using Student's $t$-test. A statistical significance level of $\mathrm{p} \leq 0.05$ was used in all evaluations.

A 2-way analysis of variance (ANOVA) was performed to examine differences in the percentage ( $\sqrt{\arcsin })$ of eggs alive at the eyed stage, factored by 
orally administered (control and E-2) and injected (water, erythromycin, azithromycin) treatments and their interactions. A retrospective power analysis was conducted to determine the probability of obtaining $\mathrm{p} \leq 0.05$ for the main effect variables and their interactions.

Statistical analysis of the experimental results was performed using $\mathrm{JMP}^{\circledR}$ (SAS Institute).

A single-phase exponential decay model, obtained by nonlinear regression of tissue antibiotic load-body burden $\left(\mu \mathrm{g} \mathrm{fish}^{-1}\right)=$ tissue concentration $\left(\mu \mathrm{g} \mathrm{g} \mathrm{g}^{-1}\right) \times$ average wet wt $(\mathrm{g})$ - versus time (GraphPad Prism Statistical Software, GraphPad Software), described the kinetics of antibiotic residue clearance (elimination rate) from the progeny of treated adults. Residue halflife $\left(t_{1 / 2}\right)$ was calculated as: $t_{1 / 2}=0.6932 \div K$, where $K$ was the elimination rate constant.

\section{RESULTS}

\section{Tissue concentrations in treated adults and their offspring}

In maturing female salmon injected, prespawning, with erythromycin, detectable quantities of the drug were found in plasma from 2 of 35 (5.7\%) fish, both spawned 12 d post-injection, and in the kidney of all fish on all spawning dates (Table 1). The mean concentration of the drug in kidney tissues ranged from 3.52 to $12.40 \mathrm{\mu g} \mathrm{g}^{-1}$. Erythromycin was measured in the coelomic fluid of all fish spawned $12 \mathrm{~d}$ post-injection, but the frequency of detection declined dramatically at each subsequent sampling. Overall, only 11 fish $(31.4 \%)$ had detectable drug in the coelomic fluid at spawning. Erythromycin was detected in the egg vitellin of all injected salmon at concentrations ranging from 5.32 to $8.87 \mu \mathrm{g} \mathrm{ml}^{-1}$.

In contrast to erythromycin, maturing female salmon injected, prespawning, with azithromycin showed high and stable concentrations of the drug in plasma, kidney, coelomic fluid, and eggs of all fish at spawning (Table 2). Mean tissue concentrations of the drug ranged from 14.66 to $20.33 \mu \mathrm{g} \mathrm{ml}^{-1}$ in plasma, 43.16 to $59.96 \mathrm{ug} \mathrm{g}^{-1}$ in the kidney, 2.52 to $5.50 \mu \mathrm{g} \mathrm{ml}^{-1}$ in the coelomic fluid, and 12.65 to $23.51 \mu \mathrm{g} \mathrm{ml}^{-1}$ in egg vitellin.

Residues of orally administered erythromycin in fish treated as subadults were not detected at spawning (Table 3). Also, subadult oral treatment with erythromycin had no detectable effect on tissue concentration of either erythromycin or azithromycin administered by prespawning injection.

Table 1. Oncorhynchus tshawytscha. Concentration of erythromycin in plasma, kidney, coelomic fluid, and eggs of female Chinook salmon sampled at spawning, 12 to $32 \mathrm{~d}$ post-injection (d.p.i.) with $40 \mathrm{mg}$ erythromycin $\mathrm{kg}^{-1}$ of body wt. Ranges are in $\mu \mathrm{g} \mathrm{g}^{-1}$ for kidney and in $\mu \mathrm{g} \mathrm{ml}^{-1}$ for plasma, coelomic fluid, and egg vitellin. E-2 fish were fed diets containing erythromycin phosphate twice each year for $2 \mathrm{yr}$ (100 mg erythromycin phosphate $\mathrm{kg}^{-1}$ of body wt $\mathrm{d}^{-1}$ for $28 \mathrm{~d}$ ) before injection; control fish were given unmedicated feed only. $\mathrm{N}$ : total number of fish sampled; number of fish with detectable erythromycin in each tissue in parentheses

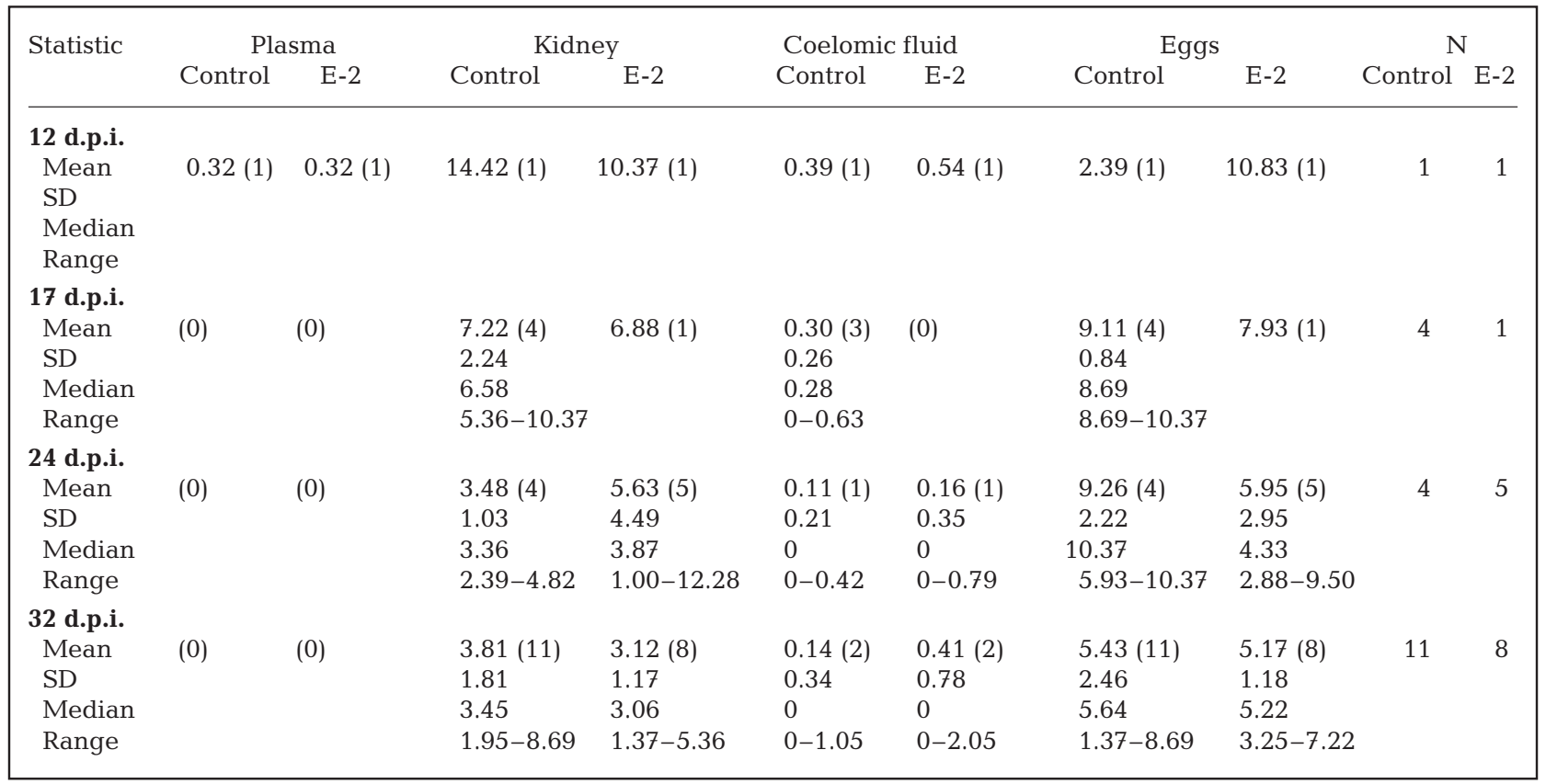


Table 2. Oncorhynchus tshawytscha. Concentration of azithromycin in plasma, kidney, coelomic fluid, and eggs of female Chinook salmon sampled at spawning, 12 to $32 \mathrm{~d}$ post-injection (d.p.i.) with $40 \mathrm{mg}$ azithromycin (base) $\mathrm{kg}^{-1}$ of body wt. N: total number of fish sampled; number of fish with detectable erythromycin in each tissue in parentheses. Further details as for Table 1

\begin{tabular}{|c|c|c|c|c|c|c|c|c|c|c|}
\hline \multirow[t]{2}{*}{ Statistic } & \multicolumn{2}{|c|}{ Plasma } & \multicolumn{2}{|c|}{ Kidney } & \multicolumn{2}{|c|}{ Coelomic fluid } & \multicolumn{2}{|c|}{ Eggs } & \multicolumn{2}{|c|}{$\mathrm{N}$} \\
\hline & Control & E-2 & Control & E-2 & Control & E-2 & Control & E-2 & Control & E-2 \\
\hline \multicolumn{11}{|l|}{12 d.p.i. } \\
\hline Mean & $14.72(3)$ & $20.71(1)$ & 47.09 (3) & 48.49 (1) & $2.03(3)$ & 4.25 (1) & 12.05 (3) & $14.43(1)$ & 3 & 1 \\
\hline $\mathrm{SD}$ & 7.64 & & 3.93 & & 0.87 & & 8.12 & & & \\
\hline Median & 11.12 & & 45.56 & & 2.07 & & 7.73 & & & \\
\hline Range & $9.55-23.50$ & & $44.15-51.55$ & & $1.14-2.87$ & & $7.01-21.42$ & & & \\
\hline \multicolumn{11}{|l|}{17 d.p.i. } \\
\hline Mean & $15.67(9)$ & $12.41(1)$ & $43.50(9)$ & 40.11 (1) & $2.41(9)$ & 3.51 (1) & 17.66 (9) & $14.43(1)$ & 9 & 1 \\
\hline $\mathrm{SD}$ & 3.29 & & 5.95 & & 0.82 & & 6.47 & & & \\
\hline Median & 16.44 & & 42.77 & & 2.45 & & 19.85 & & & \\
\hline Range & $9.19-20.05$ & & $34.01-51.55$ & & $0.44-3.34$ & & $10.22-26.68$ & & & \\
\hline \multicolumn{11}{|l|}{24 d.p.i. } \\
\hline Mean & $18.21(4)$ & $21.54(7)$ & $51.37(4)$ & $46.71(7)$ & $5.73(4)$ & $5.37(7)$ & $17.29(4)$ & $17.89(7)$ & 4 & 7 \\
\hline $\mathrm{SD}$ & 4.58 & 5.96 & 10.48 & 7.08 & 2.42 & 3.04 & 2.96 & 2.69 & & \\
\hline Median & 18.37 & 22.78 & 50.02 & 45.56 & 4.92 & 4.67 & 16.65 & 16.98 & & \\
\hline Range & $13.34-22.78$ & $13.34-30.82$ & $40.11-65.32$ & $40.11-58.13$ & $3.87-9.19$ & $1.85-11.12$ & $14.43-21.42$ & $15.04-23.08$ & & \\
\hline \multicolumn{11}{|l|}{32 d.p.i. } \\
\hline Mean & $13.02(5)$ & $16.04(6)$ & $59.97(5)$ & $62.46(6)$ & $5.13(5)$ & $5.44(6)$ & $25.57(5)$ & $21.80(6)$ & 5 & 6 \\
\hline $\mathrm{SD}$ & 5.73 & 5.06 & 6.23 & 12.38 & 3.61 & 3.43 & 7.46 & 7.17 & & \\
\hline Median & 12.41 & 17.38 & 56.43 & 63.48 & 4.67 & 4.15 & 23.08 & 20.24 & & \\
\hline Range & $7.22-20.05$ & $6.64-20.05$ & $48.49-65.32$ & $44.15-77.34$ & $1.21-9.92$ & $2.07-11.54$ & $21.42-38.83$ & $14.43-35.17$ & & \\
\hline
\end{tabular}

Table 3. Oncorhynchus tshawytscha. Summary of Student's $t$-test results for antibiotic concentrations in plasma, kidney, coelomic fluid and eggs from adult salmon that had been fed unmedicated (control) diet or administered erythromycin phosphate in the diet twice each year for $2 \mathrm{yr}(\mathrm{E}-2)$ before injection with $40 \mathrm{mg} \mathrm{kg}^{-1}$ erythromycin or azithromycin. Oral treatment with erythromycin had no significant $(p \leq 0.05)$ effect on concentration of injected drugs in any tissue tested. Analysis includes only data for tissue samples with antibiotic concentrations above detection limit

\begin{tabular}{|lccrc|}
\hline Tissue & Control (E-2) & $t$-statistic & df & $\mathrm{p}$ \\
\hline Erythromycin-treated & & & & \\
$\quad$ Plasma & 0 & - & 1 & - \\
Kidney & 0.271 & 0.249 & 33 & 0.81 \\
Coelomic fluid & -0.629 & -2.279 & 9 & 0.49 \\
Eggs & 0.709 & 0.858 & 33 & 0.40 \\
Azithromycin-treated & & & & \\
Plasma & -3.287 & -1.846 & 34 & 0.07 \\
Kidney & -3.971 & -1.160 & 34 & 0.25 \\
Coelomic fluid & -1.569 & -1.729 & 34 & 0.09 \\
Eggs & -0.322 & -0.143 & 34 & 0.89 \\
\hline
\end{tabular}

Unfed fry derived from fish injected prespawning with water or erythromycin and collected at the onset of exogenous feeding showed no traces of the drug. In contrast, azithromycin was retained in the eggs and transferred to the progeny of $100 \%$ of the fish injected, prespawning, with the drug. The mean azithromycin concentration in unfed fry was $7.35 \pm 2.87 \mu^{-1} g^{-1}$ (mean $\pm \mathrm{SD})$.

\section{Effects on egg quality}

The percentage of eggs that yielded live embryos at the eyed stage of development is summarized in Table 4.

Biologically important reductions in mean yield occurred when females treated with erythromycin as subadults were administered either erythromycin or azithromycin by prespawning injection, but no statistically significant interaction between the main effects of oral and injected treatments was detected $\left(F_{2,101}=\right.$ $1.69, \mathrm{p}=0.19)$. The experiment had low power $(0.35)$ to detect a significant difference for the interaction term in the ANOVA model, however, due to the high variability in response to the various treatment combinations (coefficient of variation $=17$ to $56 \%$ ).

Eggs derived from females injected with water had the highest yield of live embryos at the eyed stage of development $(81.52 \%)$, and was lowest in females injected with erythromycin $(72.80 \%)$. No statistically significantly effects of the prespawning-injection treatments on the yield of live embryos were detected $\left(F_{2,101}=1.93, \mathrm{p}=0.15\right)$, although the test power for the main effect of injected treatment was also low (0.39).

Eggs derived from females fed the control diet as subadults yielded a significantly higher percentage of live embryos than those given diets medicated with erythromycin $\left(F_{1,101}=6.00, \mathrm{p}=0.02\right)$. The test power for the main effect of the orally administered treatment was 0.68 . 


\section{Antibiotic residue depletion}

Azithromycin residues were detected in the tissues of juvenile salmon derived from fish injected, prespawning, with azithromycin, more than 2 mo after the onset of exogenous feeding (Fig. 1). Mean whole body burden of azithromycin was $1.85 \mu \mathrm{g} \mathrm{fish}^{-1}$ at the start of the depletion study, and was below the detection limit after $73 \mathrm{~d}$ of feeding. The body burden-time profiles followed a single-compartment exponential decay model $\left(y=2.695 \times 2.71828^{(-0.02004 x)}-0.6369\right)$, which explained $74.9 \%$ of the variation of the samples, estimated as the coefficient of variation $\left(R^{2}\right)$. The elimination half-life was $34.6 \mathrm{~d}$.

Table 4. Oncorhynchus tshawytscha. Mean $( \pm \mathrm{SD})$ percentage viable embryos at eyed stage derived from female Chinook salmon treated orally with erythromcyin as subadults followed by prespawning injections with either water, erythromycin or azithromycin. As subadults, fish were fed unmedicated (control) diet or administered erythromycin phosphate in diet twice each year for $2 \mathrm{yr}$ (E-2; $100 \mathrm{mg}$ erythromycin $\mathrm{kg}^{-1}$ of body wt $\mathrm{d}^{-1}$ for $28 \mathrm{~d}$ ). Antibiotic injections (40 $\mathrm{mg} \mathrm{kg}^{-1}$ of body wt) were administered 12 to $32 \mathrm{~d}$ before spawning. Main oral eff: main effects of oral treatments; Main inject. eff: main effects of injection treatments

\begin{tabular}{|c|c|c|c|c|}
\hline & \multicolumn{3}{|c|}{ Injection treatment } & \multirow[t]{2}{*}{ Main oral eff } \\
\hline & Water & Azithromycin & Erythromycin & \\
\hline Oral control & $82.76(25.01)$ & 82.78 (21.85) & $83.26(14.07)$ & $82.92 \quad(20.73)$ \\
\hline Oral E-2 & 79.35 (24.60) & 73.63 (25.63) & $58.86(33.01)$ & $70.21 \quad(28.83)$ \\
\hline Main inject. eff & $81.52(24.57)$ & $78.96(23.59)$ & $72.80(26.64)$ & \\
\hline
\end{tabular}

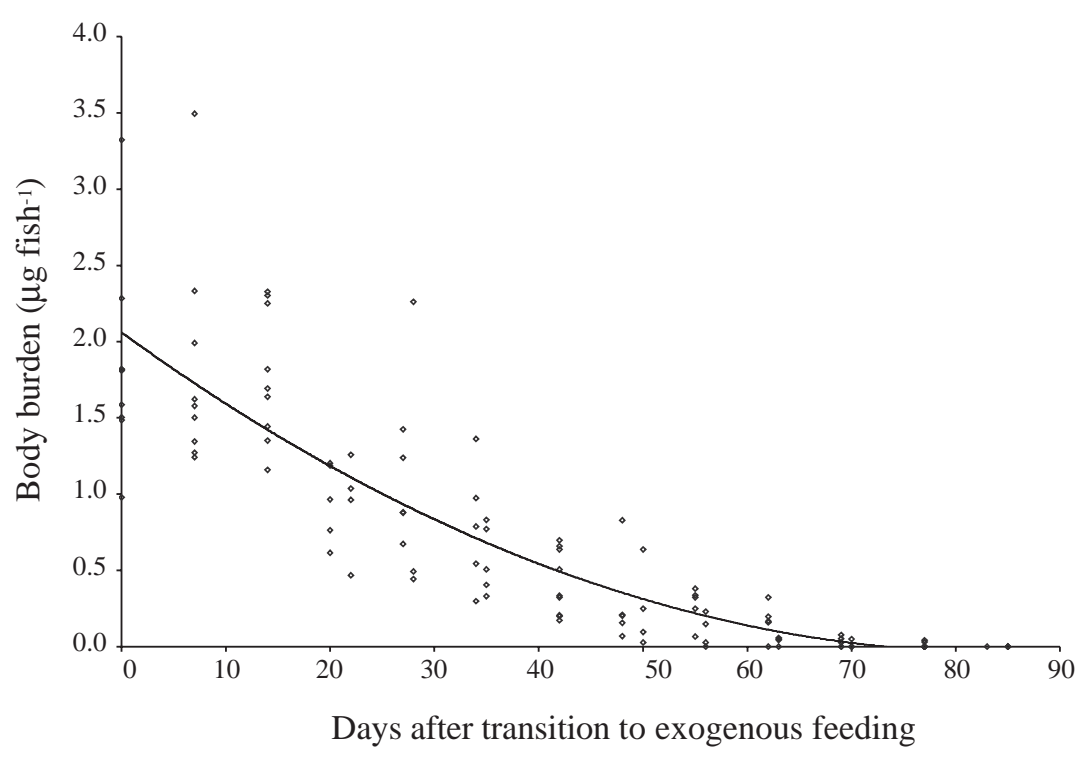

Fig. 1. Oncorhynchus tshawytscha. Body burden $\left(\mu \mathrm{g} \mathrm{fish}^{-1}\right)$ of azithromycin in progeny of female fall Chinook salmon injected with $40 \mathrm{mg}$ azithromycin (base) $\mathrm{kg}^{-1}$ body wt before spawning. The fish increased in weight from 0.27 to $2.08 \mathrm{~g}$ during the $85 \mathrm{~d}$ residue depletion study. Mean elimination half-life was $34.6 \mathrm{~d}$

\section{DISCUSSION}

Oral exposure of subadult salmon to erythromycin had no apparent effect on the peak tissue concentratration of ery observed. In humans and rats, adminisbered ring macrolide antibiotics with a tertiary amine function) can first induce hepatic cytochrome P-450 and then inhibit its (their) own metabolism by forming stable cytochrome P-450-Fe(II)-metabolite complexes (Amacher et al. 1991). This phenomenon could lead to decreased elimination of erythromycin (and related macrolide antibiotics, such as azithromycin), potentially leading to secondary toxic effects.

Orally administered erythromycin is rapidly cleared from the tissues of juvenile salmon (Moffitt \& Schreck 1988, Fairgrieve et al. 2005), but is more persistent in prespawning adults repeatedly exposed to the antibiotic. Fairgrieve et al. (2004) detected erythromycin ( 0.4 to $13.7 \mu^{-1} \mathrm{~g} \mathrm{~g}^{-1}$ ) in the kidney of 17 to $57 \%$ of reproductively mature Chinook salmon 78 to $103 \mathrm{~d}$ after treatment ended. In the present study, however, oral administration of erythromycin ended 14 mo before spawning and no residues from these treatments were detected, so acutely toxic interactions were unlikely to occur. Whether these results also apply to hatchery broodstock populations, to which erythromycin is given prophylactically at regular intervals in medicated feeds and also by injection to control BKD epizootics in subadult salmon, should be investigated.

In adult females injected, prespawning, with erythromycin, no residues of the drug were in the plasma $17 \mathrm{~d}$ postinjection. Residues were detected only infrequently in the coelomic fluid, but they persisted in the kidney and egg vitellin for at least $32 \mathrm{~d}$. These results agree with previous broodstock trials in which erythromycin residues were observed in only $42 \%$ of plasma samples $20 \mathrm{~d}$ after fish were injected with $40 \mathrm{mg} \mathrm{kg}^{-1}$ (Moffitt \& Kiryu 1999) but persisted in the kidney for at least $28 \mathrm{~d}$ (Haukenes \& Moffitt 2002). Intra-ovum erythromycin levels exceeding the 
minimum inhibitory concentration for Renibacterium salmoninarum have also been observed in salmonids injected 30 to $56 \mathrm{~d}$ before spawning (Evelyn et al. 1986b). Nevertheless, azithromycin exhibited a clear pharmacokinetic advantage over erythromycin, demonstrated by the high, stable concentrations maintained in blood plasma, kidney, coelomic fluid and egg vitellin of maturing female salmon throughout the $32 \mathrm{~d}$ spawning period. These findings are of particular clinical relevance, because eggs may acquire infections during oogenesis (Lee \& Gordon 1987) or from contaminated coelomic fluid following ovulation (Lee \& Evelyn 1989).

No negative effects of erythromycin or azithromycin, injected prespawning, on the fertilized eggs were found in the present study. Among the groups fed the unmedicated control diet before injection, mean viable progeny yield to the eyed stage was greater than $82 \%$. Similarly, Moffitt \& Kiryu (1999) injected maturing Chinook salmon with $40 \mathrm{mg}$ erythromycin $\mathrm{kg}^{-1}$ of body weight every $20 \mathrm{~d}$ up to 6 times before sexual maturity, and observed mean progeny yields ranging from 71.3 to $93.9 \%$.

Significantly, reductions in the percentage of eggs that yielded live embryos at the eyed stage of development occurred among eggs derived from females that had been orally administered erythromycin during the subadult stage of the present study. These results confirm those of Fairgrieve et al. (2004) for Chinook salmon given multiple therapeutic dosages of erythromycin in their diets as subadults. Those fish exhibited increased prevalences of ovarian atresia, reduced fecundity and lower yields of viable embryos.

Detrimental reproductive effects associated with orally administered erythromycin treatment have not been previously reported in the scientific literature, and the mechanisms responsible remain unknown. Because eggs without viable embryos rapidly deteriorated after shocking, neither the fertilization rates nor the developmental status of the dead embryos that were frequently observed could be determined from the samples collected at that time. Our results (Fairgrieve et al. 2004), however, linking follicular atresia and egg quality, indicated that the effects of erythromycin occurred during early stages of oogenesis, but were manifest only later. Importantly, these reductions in reproductive yield appear to have been exacerbated by prespawning injection with either azithromycin or erythromycin. Further research focused on these apparently toxic interactions is clearly warranted.

In this comparative study with Chinook salmon, azithromycin, but not erythromycin, was detected in the progeny of injected females at the onset of exogenous feeding. Erythromycin deposited in the egg before spawning is well known to persist throughout egg incubation and into the alevin stage (Brown et al. 1990), but its persistence during the early stages of yolk sac adsorption has not been previously evaluated. In the present study, residues of erythromycin were already below the level of detection at the onset of exogenous feeding. In contrast, residues of azithromycin were detected in progeny of injected adult salmon for more than 2 mo after the onset of exogenous feeding. These results agree with data from laboratory feeding trials with juvenile Chinook salmon, in which erythromycin residues were below detection within $21 \mathrm{~d}$ following treatment, but azithromycin was present for at least $74 \mathrm{~d}$ after drug withdrawal (Fairgrieve et al. 2005).

The present trial provides a preliminary model of the absorbance, distribution and depletion of azithromycin in the tissues of maturing female Chinook salmon, and of its persistence in the eggs and progeny of treated females. Compared with erythromycin, the consistently higher tissue concentrations and prolonged retention of azithromycin in mature Chinook salmon may increase its effectiveness in preventing transmission of Renibacterium salmoninarum via infected eggs. The presence of therapeutically relevant concentrations of azithromycin in the progeny may also serve to control horizontal transmission of the pathogen among cohabiting first-feeding juveniles.

Acknowledgements. This work was supported by the U.S. Department of Energy and Bonneville Power Administration under contract no. 99-AI-17859. The authors acknowledge K. Shearer and D. Frost for technical assistance with this project.

\section{LITERATURE CITED}

Amacher DE, Schomaker SJ, Retsema JA (1991) Comparison of the effects of the new azalide antibiotic, azithromycin, and erythromycin estolate on rat liver cytochrome P-450. Antimicrob Agents Chemother 35:1186-1190

Bandin I, Ellis AE, Barja JL, Secombes CJ (1993) Interaction between rainbow trout macrophages and Renibacterium salmoninarum in vitro. Fish Shellfish Immunol 3:25-33

Brown LL, Albright LJ, Evelyn TPT (1990) Control of vertical transmission of Renibacterium salmoninarum by injection of antibiotics into maturing female coho salmon Oncorhynchus kisutch. Dis Aquat Org 9:127-130

Bullock GL, Leek SL (1986) Use of erythromycin in reducing vertical transmission of bacterial kidney disease. Vet Hum Toxicol 28:18-20

Butterbaugh GL, Willoughby H (1967) A feeding guide for brook, brown, and rainbow trout. Prog Fish-Cult 29: 210-215

Earp BL, Ellis CH, Ordal EJ (1953) Kidney disease in young salmon. Special Report Series (1). Washington Department of Fisheries, Olympia, WA

Elliott DG, Pascho RJ, Bullock GL (1989) Developments in the control of bacterial kidney disease in salmonid fishes. Dis Aquat Org 6:201-215 
Evelyn TPT, Ketcheson JE, Prosperi-Porta L (1986a) Experimental intra-ovum infection of salmonid eggs with Renibacterium salmoninarum and vertical transmission of the pathogen with such eggs despite their treatment with erythromycin. Dis Aquat Org 1:197-202

Evelyn TPT, Ketcheson JE, Prosperi-Porta L (1986b) Use of erythromycin as a means of preventing vertical transmission of Renibacterium salmoninarum. Dis Aquat Org 2: 7-11

Fairgrieve WT, Masada CL, McAuley WC, Peterson ME, Myers MS, Strom MS (2004) Use of antibiotics and new vaccines to reduce mortality from bacterial kidney disease in Chinook salmon: evaluation of toxic effects of long-term prophylactic use of azithromycin and erythromycin. Final Report for FY 1999-2002. In: Berejikian BA, Nash CE (eds) Research on captive broodstock programs for Pacific salmon, Report to Bonneville Power Administration for FY02, Project No. 1993-056-00, Contract No. 99-AI17859, Appendix A

Fairgrieve WT, Masada CL, McAuley WC, Peterson ME, Myers MS, Strom MS (2005) Accumulation and clearance of orally administered erythromycin and its derivative, azithromycin, in juvenile fall Chinook salmon Oncorhynchus tshawytscha. Dis Aquat Org 64:99-106

Flagg TA, Mahnken CVM, Johnson KA (1995) Captive broodstocks for recovery of Snake River sockeye salmon. In: Schramm HL, Piper RG (eds) Uses and effects of cultured fishes in aquatic ecosystems. Am Fish Soc Symp 15:81-90

Fryer JL, Lannan CN (1993) The history and current status of Renibacterium salmoninarum, the causative agent of bacterial kidney disease in Pacific salmon. Fish Res 17:15-33

Girard AE, Girard D, English AR, Gootz TD, Cimochowski CR, Faiella JA, Haskell SL, Retsema JA (1987) Pharmacokinetic and in vivo studies with azithromycin (CP-62,993), a new macrolide with an extended half-life and excellent tissue distribution. Antimicrob Agents Chemother 31:1948-1954

Gutenburger SK, Duimstra JR, Rohovec JS, Fryer JL (1997) Intracellular survival of Renibacterium salmoninarum in trout mononuclear phagocytes. Dis Aquat Org 28:93-106

Haukenes AH, Moffitt CM (2002) Hatchery evaluation of erythromycin phosphate injections in prespawning spring Chinook salmon. N Am J Aquac 64:167-174

Editorial responsibility: Dave Bruno,

Aberdeen, UK
Lee EGH, Evelyn TPT (1989) Effect of Renibacterium salmoninarum levels in the ovarian fluid of spawning chinook salmon on the prevalence of the pathogen in their eggs and progeny. Dis Aquat Org 7:179-184

Lee EGH, Evelyn TPT (1994) Prevention of vertical transmission of the bacterial kidney disease agent renibacterium salmoninarum by broodstock injection with erythromycin. Dis Aquat Org 18:1-4

Lee EGH, Gordon MR (1987) Immunoflorescence screening of Renibacterium salmoninarum in the tissues and eggs of farmed Chinook salmon spawners. Aquaculture 65:7-14

Moffitt CM, Kiryu Y (1999) Toxicity, teratogenesis, and efficacy of injectable erythromycin (Erythro-200) administered repeatedly to adult spring Chinook salmon. J Aquat Anim Health 11:1-9

Moffitt CM, Schreck JA (1988) Accumulation and depletion of orally-administered erythromycin thiocyanate in the tissues of Chinook salmon. Trans Am Fish Soc 117:394-400

Peters DH, Freidel HA, McTavish D (1992) Azithromycin. A review of its antimicrobial activity, pharmacokinetic properties, and clinical efficacy. Drugs 44:750-799

Peters KK, Moffitt CM (1996) Optimal dosage of erythromycin thiocyanate in the new feed additive to control bacterial kidney disease. J Aquat Anim Health 8:229-240

Sakai M, Kobayashi M (1992) Detection of Renibacterium salmoninarum, the causative agent of bacterial kidney disease in salmonid fish, from pen-cultured coho salmon. Appl Environ Microbiol 58:1061-1063

Strom MS, Fairgrieve WT, Harrell L, Rathbone CK (2000) Efficacy and toxicity of treatments for bacterial kidney disease in Chinook salmon. In: Berejikian BA (ed) Research on captive broodstock programs for Pacific salmon, FY 2000 Annual Report to Bonneville Power Administration, Contract No. 99-AI-17859, p 105-110

Toranzo AE, Santos Y, Bandin I, Romalde JL, Ledo A, Fouz B, Barja JL (1990) Five year survey of bacterial fish infections in continental and marine aquaculture in northwest Spain. World Aquacult 21:91-94

Wolf K, Dunbar CE (1959) Test of 34 therapeutic agents for control of kidney disease in trout. Trans Am Fish Soc 88: $117-124$

Submitted: February 9, 2005; Accepted: June 16, 2005

Proofs received from author(s): February 10, 2006 